\title{
VERTEBROMETRY AND DISCOMETRY OF THE LUMBAR FUNCTIONAL SEGMENT (REBATÚ-MURGUÍA TECHNIQUE)
}

\author{
VERTEBROMETRIA E DISCOMETRIA DO SEGMENTO LOMBAR FUNCIONAL \\ (TÉCNICA REBATÚ-MURGUÍA) \\ VERTEBROMETRÍA Y DISCOMETRÍA DEL SEGMENTO FUNCIONAL LUMBAR \\ (TÉCNICA REBATÚ-MURGUÍA)
}

Alejandro González Rebatú y González ${ }^{1}$, Ramón Ortega Padron, ${ }^{1}$ Myriham Murguia Casas, ${ }^{1}$ Rubén Vargas Burgos ${ }^{1}$,

Rodrigo Bartolomé Vargas Lugo Salinas ${ }^{1}$

1. Hospital Regional 1ero. De Octubre ISSSTE, Ciudad de México, Distrito Federal.

\begin{abstract}
Surgical treatment of intervertebral disc degeneration aims to restore the height of the disc space and the release of involved neurological structures. Like any surgical treatment in orthopedics, the success or failure of the lumbar procedure involves the possibility of performing an adequate planning of each particular event. In the case of lumbar stabilization surgery with interbody fusion, it is essential to know the ideal height of the disc space for the fusion to be successful. Objective: To demonstrate that the ideal height of the disc space corresponds approximately to one third of the height of the vertebral body. Methods: X-ray images were taken in AP and lateral views of hospital residents to measure L4-L5 vertebral bodies as well as the disc space. The rule of three was used to check the height of the disc and vertebral bodies. Results: It was verified that the disc space corresponds to $31 \%$ of the size of the vertebral body, taking 0.31 as the constant. Conclusions: The size of the disc corresponds to one third of the vertebral body, taking 0.31 as the constant. The multiplication of the constant by the height of the vertebral body results in the exact height of the disc. Thus, in the presence of degeneration of the intervertebral disc, it is possible to know the size of the disc and, therefore, the size of the interbody cage.
\end{abstract}

Keywords: Intervertebral disc degeneration; Diskectomy; Spinal fusion.

\section{RESUMO}

O tratamento cirúrgico da degeneração de disco intervertebral visa restaurar a altura do espaço discal e a liberação de estruturas neurológicas envolvidas. Como qualquer tratamento cirúrgico em ortopedia, o sucesso ou fracasso do procedimento lombar envolve a possibilidade de realizar um planejamento adequado de cada evento em particular. Em se tratando de cirurgia de estabilização lombar com fusão intersomática, é essencial conhecer a altura ideal do espaço discal para que a fusão seja bem-sucedida. Objetivo: Demonstrar que a altura ideal do espaço discal corresponde aproximadamente a um terço da altura do corpo vertebral. Métodos: Foram realizadas radiografias em visão AP e lateral em residentes do hospital para fazer a medição dos corpos vertebrais do segmento funcional L4-L5, assim como do espaço discal. Realizou-se uma comprovação da regra de três com a altura do disco e dos corpos vertebrais. Resultados: Verificou-se que o espaço discal equivale a 31\% do tamanho do corpo vertebral, tomando-se como constante 0,31. Conclusão: O tamanho do disco é correspondente a um terço do corpo vertebral, tomando-se um constante 0,31. A multiplicação da constante pela altura do corpo vertebral resulta na altura exata do disco. Assim sendo, em presença de degeneração do disco intervertebral, é possível conhecer o tamanho do disco e, portanto, o tamanho do cage intersomático.

Descritores: Degeneração do disco intervertebral; Discotomia; Fusão vertebral.

\section{RESUMEN}

El tratamiento quirúrgico de la enfermedad discal degenerativa tiene como objetivo reestablecer la altura del espacio discal y la liberación de estructuras neurológicas involucradas. Como cualquier tratamiento quirúrgico en ortopedia, el éxito o fracaso de la cirugía lumbar consiste en la posibilidad de realizar una adecuada planeación de cada evento en particular. Hablando de la cirugía de estabilización lumbar con fusión intersomática, conocer la altura ideal del espacio discal es indispensable para una fusión exitosa. Objetivo: Demostrar que la altura ideal del espacio discal corresponde aproximadamente a una tercera parte de la altura del cuerpo vertebral. Métodos: Fueron tomadas radiografías en vista AP y lateral de residentes del hospital para realizar la medición de los cuerpos vertebrales del segmento funcional L4-L5 así como del espacio discal. Se realizó una comprobación de la regla de tres con la altura discal y de los cuerpos vertebrales. Resultados: Se encontró que el espacio discal equivale al 31\% del tamaño del cuerpo vertebral, tomándose como constante 0,31. Conclusión: El tamaño del disco equivale a la tercera parte del cuerpo vertebral, tomándose la constante 0,31. La multiplicación de la constante por la altura del cuerpo vertebral, resulta en la altura exacta del disco. Por lo tanto, en presencia de discartrosis, es posible conocer el tamaño del disco y, por lo tanto, el tamaño de la caja intersomática.

Descriptores: Degeneración del disco intervertebral; Discectomía; Fusión vertebral. 


\section{INTRODUCTION}

Surgical treatment of degenerative disc disease aims to reestablish the height of the disc space and to release the neurological structures involved. Like any surgical treatment in orthopedics, the success or failure of lumbar surgery depends on the adequate planning of each particular event. Speaking of lumbar stabilization surgery with interbody fusion, it is essential to know the ideal height for the disc space for a successful interbody fusion.

Several authors have described the size of the disc space in the vertebral segment. The way to measure the disc space has been studied and described, however, the way to calculate the ideal disc space in patients with degenerative disc disease has not been described.

There is no similar work that describes the calculation of the ideal disc space size based on the measurement of the vertebral body (vertebrometry-discometry) in the functional L4-L5 vertebral segment (vertebra-disc-vertebra).

Our objective is to demonstrate that the ideal disc space corresponds to approximately one third of the height of the vertebral body, and thus, to achieve a specific constant to determine the ideal height of the disc space and, with it, to be able to determine the ideal size of the interbody cage to use in instrumentation with interbody fusion.

\section{BACKGROUND}

Intervertebral discs are anatomical elements located between the vertebral bodies along the entire length of the spine, with the exception of the first cervical vertebrae and the sacrococcygeal region. ${ }^{1}$ They are constructed in the center by the nucleus pulposus that is composed of a polysaccharide mucoprotein gel with a fibrous ring at the periphery formed by concentric bands of firmly adhered elastic fibers positioned at an inclination of $30^{\circ}$ in various directions that are fixed to the lower and upper levels of the supra- and subjacent vertebrae, respectively. The external fibers have greater resistance than the others, since they are integrated with the bony tissue of the vertebral body at the edge of the level. ${ }^{2}$

The nucleus pulposus is sealed within a closed space, acting like a hydraulic chamber, with a water content of between 70 and $90 \%$ at birth that dehydrates progressively with age. Its proportional dimensions are smaller in the cervical spine and they are larger in the lumbar spine. ${ }^{1,2}$

Its anatomical characteristics give it qualities that allow it to perform specific mechanical functions such as the junction between the vertebral levels that is accomplished by the firm insertion of the fibers of the annulus that are anchored to the vertebral bodies during normal movements performed by the spine, also maintaining the alignment of the assembly assisted by the other anterior and posterior ligaments. Its function as a hydraulic chamber, performed by the displacements of the nucleus pulposus and the elasticity of the surrounding fibers of the ring allow it to support the forces transmitted to its axis and to distribute the load uniformly to the underlying body. ${ }^{1-3}$

Another function of the intervertebral disc is to reduce the load on the vertebral articulations of the supra- and subjacent vertebral bodies, which permits a reduction in the friction between the joint surfaces. The effect of distributing the load between the disc and posterior joints was the foundation for the theory of the three joints, a well-accepted proposal, but one that leads to considering the junction of the vertebral bodies through the disc as a single joint and not as the axis of rotation as it actually acts as from a mechanical point of view. ${ }^{3}$

One of the major economic problems in today's world is degenerative diseases of the spine. The costs of diagnosis, treatment and rehabilitation, as well as the economic impact due to absenteeism, lead to lost productivity and have become the biggest issue behind getting these patients that make up the economically active population back to the workplace. ${ }^{4}$ Regardless of the labor and economic problems caused by degenerative diseases, an efficient definition of the causative factor of the symptomology takes priority, aimed at offering the patient an early alternative of treatment that leads to an adequate remission of the clinical profile.
Degenerative changes of the lumbar spine are established by multiple factors such as congenital malformations, from "physiological" wear or as a consequence of traumatic events or varying degrees, such as physical microtraumas during an individual's life from standing, the action of walking on various inclination planes, high- and medium-impact sports activities, as well as going up and down stairs and running, changing the conditions of dynamic stability or the structural alignment of the various elements that make up the spine. ${ }^{5}$

In the normal evolution of aging of the human body, there are modifications of the bone structures of the spine and of the soft tissues that, associated with congenital or acquired factors, can predispose one to or accelerate the degeneration of the different elements that make up the spine. These changes are often accompanied by degenerative changes in the muscle groups that support the spine, creating a condition of weakened muscle strength, susceptible to a predisposition to degeneration of the intervertebral discs and facet joints, as well as favoring thickening of the yellow ligaments and the formation of hypertrophic processes in the vertebral bodies causing spinal stenosis. ${ }^{4-6}$

One theory about vertebral degeneration assumes that all spines degenerate and that, as such, our usual treatment methods serve as the treatment for three separate stages with relatively distinct findings. ${ }^{3,7}$

The first stage is dysfunction. This stage is found in the 15 to 45 years of age group. It is characterized by circumferential and radial rupture in the fibrous ring and synovitis of the interapophyseal joints.

The next stage is instability. This stage, in patients from 35 to 70 years of age, is characterized by the internal disruption of the disc, degeneration of the interapophyseal joints with capsular laxity, subluxation, and articular erosion.

The final stage is stabilization, found in patients older than 60 years of age. In this stage, the progressive development of hypertrophic bone around the disc and the interapophyseal joints leads to segmental rigidity or to frank ankylosis.,

Each vertebral segment degenerates to a different rhythm. While one level may be in a state of dysfunction, another may be in a state of stability. Disc herniation in this scheme is considered to be a complication of disc degeneration in the dysfunction and stability stages.

When a patient is referred to our unit for evaluation with a suspected diagnosis of degenerative disc disease, diagnosis and planning are focused on the results obtained from a careful anamnesis and an extensive physical examination of the patient, and subsequently of what is reflected in the imaging studies of each particular case.

Computed tomography (CT) and magnetic resonance (MR) are the imaging studies of choice for degenerative disc disease, radiographical evaluation has been set aside in the planning phase of spine surgery. However, in our institutional hospital environment, simple radiography of the spine remains the most available study for the patient's imaging evaluation.

In our hospital unit, the patients are referred from secondary care, after going through primary care, so that we receive only patients with lumbar pathology that does not respond to conservative management. For this reason, obtaining the disc space using traditional methods only permits us to know the size of the already damaged disc, without being able to determine the ideal disc space for its restitution with the interbody cage at the time of the surgical procedure.

\section{METHODS}

The study was approved by the Institutional Review Board of the Hospital Regional $1^{\circ}$ de Octubre ISSSTE (\#003). The participants signed the Informed Consent Form for the study.

A campaign was held among the residents of all the specialties to recruit those without degenerative disc disease. Resident physicians of all levels and in all the specialties of the hospital were invited to take AP and profile radiographs of the lumbosacral spine for evaluation and for the early detection of lumbar spine ailments. The objective was to find participants between 20 and 30 years of age, without degenerative disc pathology in order to take measurements of the functional segment (vertebrometry and discometry) by already described methods (Frobin's method). ${ }^{8}$ 


\section{RESULTS}

A total of 23 residents entered the campaign, 11 of whom were eliminated from the study; 8 for being older than 30 years of age and 3 who were within the age range necessary for the study, but who had some degenerative spine problem (in one of them we observed Grade II spondylolisthesis, in another scoliosis, and one had segmentation changes). Thus, we included 12 patients in the study, 4 of whom were women (33.33\%) and 8 of whom were men (66.66\%), aged from 27-30, with an average age of 28.6 years.

Anthropometric measurements were taken with an average height of 1.7 meters, an average weight of $75.9 \mathrm{~kg}$, and an average BMl of 26.21. (Table 1)

Vertebrometry of L4 and L5 and discometry of L4-L5 were performed using the Frobin method. Measurements of between 31 and $41 \mathrm{~mm}$ with an average of $34.16 \mathrm{~mm}$ and between 31 and $42 \mathrm{~mm}$ with an average of 34.75 were obtained for L4 and L5 respectively. The discometry reported measurements of from 9 to $13 \mathrm{~mm}$, with an average of $10.66 \mathrm{~mm}$. (Figure 1)

We calculated a ratio using the rule of three between the height of the vertebral body and the height of the disc space, with percentages ranging from 28.57 to $32.35 \%$, and an average of $30.68 \%$ in relation to the vertebral height of $L 4$ and percentages ranging from 26.47 to $33.33 \%$, with an average of $31.25 \%$. When we calculated the ratio between the average measurement of the vertebral bodies and the average height of the disc space, we got a proportion of $30.92 \%$ (31\%). (Figure 2)

\section{CONCLUSION}

Through measurements and the calculation of ratios using the rule of three, we can conclude that the disc height corresponds to approximately $31 \%$ of the vertebral height in the L4-L5 lumbar functional segment, giving us a constant of 0.31 .

Therefore, in patients with discarthrosis, where reestablishing the ideal disc height is the goal, the height of the vertebral bodies in millimeters can be used as a reference and multiplied by 0.31 to obtain the ideal size of the interbody cage to be used for interbody arthrodesis.

In this way, a simple multiplication can be performed on our preoperative measurements to be able to perform the surgery with certainty about the height of the disc space.

All authors declare no potential conflict of interest related to this article.

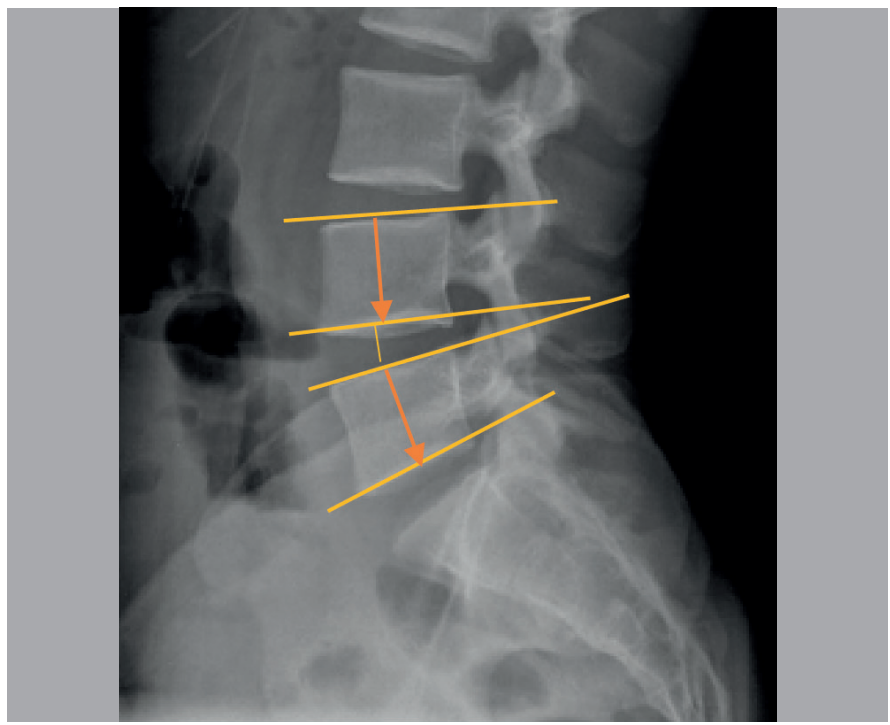

Figure 1. Body measurement.

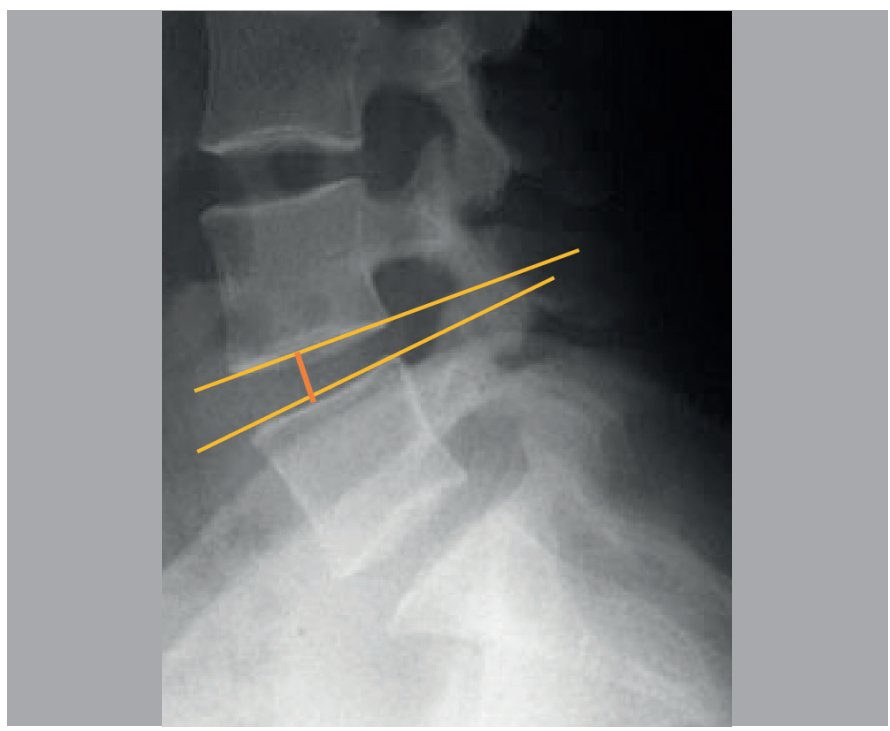

Figure 2. Measurement of the disc.

Table 1. Anthropometric vertebrometry and discometry measurements of the patients.

\begin{tabular}{|c|c|c|c|c|c|c|c|c|}
\hline Patient & Age & Sex & Height (M) & Weight $(\mathrm{Kg})$ & BMI & $\begin{array}{l}\text { L4 Vertebral } \\
\text { height (mm) }\end{array}$ & $\begin{array}{l}\text { L5 Vertebral } \\
\text { height }(\mathrm{mm})\end{array}$ & $\begin{array}{l}\text { L4-L5 Disc space } \\
\text { height }(\mathrm{mm})\end{array}$ \\
\hline 1 & 27 & Female & 1.56 & 60 & 24.65 & 31 & 33 & 10 \\
\hline 2 & 29 & Male & 1.72 & 95 & 32.11 & 36 & 36 & 11 \\
\hline 3 & 26 & Male & 1.7 & 77 & 26.64 & 33 & 34 & 10 \\
\hline 4 & 29 & Female & 1.62 & 70 & 26.67 & 33 & 34 & 11 \\
\hline 5 & 30 & Male & 1.9 & 70 & 19.39 & 41 & 42 & 13 \\
\hline 6 & 30 & Male & 1.75 & 75 & 24.49 & 34 & 36 & 11 \\
\hline 7 & 30 & Female & 1.58 & 58 & 23.23 & 31 & 33 & 10 \\
\hline 8 & 30 & Male & 1.82 & 90 & 27.17 & 35 & 35 & 10 \\
\hline 9 & 30 & Male & 1.73 & 80 & 26.73 & 33 & 34 & 11 \\
\hline 10 & 26 & Female & 1.62 & 79 & 30.10 & 34 & 31 & 9 \\
\hline 11 & 28 & Male & 1.76 & 82 & 26.47 & 33 & 34 & 11 \\
\hline 12 & 28 & Male & 1.67 & 75 & 26.89 & 36 & 35 & 11 \\
\hline
\end{tabular}


CONTRIBUTION OF THE AUTHORS: Each author made significant individual contributions to this manuscript. AGRG and MMC were the principal contributors to the writing of the manuscript, ROP, to traditional knowledge, RVB and RBVLS analyzed the patient follow-up, measured the radiographs, and collected the clinical data. RVB and MMC evaluated the statistical analysis data. AGRG, ROP, and RBVLS researched the literature, reviewed the manuscript, and contributed to the intellectual concept of the study.

\section{REFERENCES}

1. Reddy $P$, Williams $R$, Willis $B$, Nanda A. Pathological evaluation of intervertebral disc tissue specimens after routine cervical and lumbar decompression. A cost-benefit analysis retrospective study. Surg Neurol. 2001;56(4):252-5.

2. Duffo Olvera M, Duffo Villegas M, Preciado Salgado MA. Criterios de tratamiento de la hernia discal aislada y de las hernias discales múltiples. Ortho-tips. 2005; 1(2):77-93.

3. Keith D, Williams A, Park L. Dolor lumbar y trastornos del disco vertebral. In: Canale ST. Campbell cirugía ortopédica. $11^{\text {a }}$ edición. España: Elseiver; 2010. p. 2159-236.

4. Boleaga-Durán B. Conceptos básicos de la enfermedad lumbar degenerativa. An Radiol México. 2007:1:51-61.
5. Boleaga BD, Corona RC, Silva PR, Fernández ST, Romero BLB. Enfermedad lumbar degenerativa. Rev Mex Radiol. 1995:49(4):163-72.

6. Seidenwurm D, Litt AW. The natural history of lumbar spine disease. Radiology. 1995;195(2):323-4.

7. Modic MT. Degenerative disorders of the spine. In: Modic MT, MasarykTJ, Ross JS, editors. Magnetic resonance imaging of the spine. Chicago: Year Book Medical Publishers: 1989. p. $75-119$.

8. Frobin W, Brinckmann P, Biggemann M, Tillotson M, Burton K. Precision measurement of disc height, vertebral height and sagittal plane displacement from lateral radiographic views of the lumbar spine. Clin Biomech (Bristol, Avon). 1997;12(Suppl 1):S1-S63. 